\title{
A

\section{International Journal of}

Pediatrics, Neonatology and Primary Care \\ GH Provocative Test in Diagnosis of GH deficiency in Childhood, Can We Trust on Them?}

\author{
María Amparo López Ruiz
}

Department of Biomedical Sciences, Faculty of Health Sciences, CEU Cardenal Herrera University, Valencia, Spain

\section{Article Info}

\section{*Corresponding author: \\ María Amparo López Ruiz \\ Department of Biomedical Sciences \\ Faculty of Health Sciences \\ CEU Cardenal Herrera University \\ Valencia, Spain \\ E-mail: maria.lopez5@uchceu.es}

\section{Received: April 20, 2019 \\ Accepted: April 27, 2019 \\ Published: May 3, 2019}

Citation: Lopez-Ruiz M. GH Provocative Test in Diagnosis of $\mathrm{GH}$ deficiency in Childhood, Can We Trust on Them? Int J Pediatr Neonatal Prim Care. 2019; 1(1): 21-23.

doi: 10.18689/ijpn-1000106

Copyright: (c) 2019 The Author(s). This work is licensed under a Creative Commons Attribution 4.0 International License, which permits unrestricted use, distribution, and reproduction in any medium, provided the original work is properly cited.

Published by Madridge Publishers

\begin{abstract}
The most common reason for referral a Paediatric patient to the Endocrinologist is short stature. But the diagnosis of growth hormone deficiency (GHD) in childhood is a big challenge, due to the lack of gold standard tests.

The GDH can be total (the diagnosis is easy to suspect: pituitary lesions or congenital deficiency) or partial (diagnosis is more complex - cases are not accompanied by any clinic) when it will be necessary to do GH provocative tests.

Thus most common provocative tests of $\mathrm{GH}$ release (insulin tolerance test (hypoglycaemia), L-dopa, arginine, glucagon, propranolol, clonidine and GHRH) are used to determine GH status. But, for the definitive diagnosis not only will be necessary the provocative test results, it Will always be necessary to take into consideration also the clinical criteria together with auxological and biochemical parameters.
\end{abstract}

Conclusion: It would be advisable to use provocative tests of $\mathrm{GH}$ release with the highest percentages of sensitivity and specificity to detect subjects with GHD (insulin tolerance test "gold standar") but always excluding patients with an adequate $\mathrm{GH}$ response before.

Keywords: Provocative Test; Growth Hormone Deficiency; Arginine; Glucagon.

\section{Introduction}

Nowadays, the most common reason for referral a Paediatric patient to the Endocrinologist is short stature. [1]. But the diagnosis of growth hormone deficiency (GHD) in childhood is a big challenge [2]. Due to the lack of gold standard tests, provocative $\mathrm{GH}$ tests are still considered the primary role in the diagnosis of GHD. So, the purpose of this review is to evaluate the usefulness of a variety of $\mathrm{GH}$ provocative test in the diagnosis of GHD in children.

The GDH can be total or partial. In the cases of total GDH (pituitary lesions or congenital deficiency), the diagnosis is easy to suspect. But in the cases of partial deficiencies, most of the cases are usually not accompanied by any clinic so the diagnosis is usually more complex and it will be necessary to do $\mathrm{GH}$ provocative tests. The consensus guidelines of the Growth Hormone Research Society for diagnosis and treatment of GHD in children have established that in a child with suspected isolated GHD, two stimulation tests are required [3].

\section{Tests to Assess GH Secretion}

$\mathrm{GH}$ secretion is pulsatile and serum concentrations are low during many hours of the day [4]. Thus provocative tests of $\mathrm{GH}$ release are used to determine $\mathrm{GH}$ status. The most common provocative tests of $\mathrm{GH}$ release are: insulin tolerance test (hypoglycaemia), L-dopa, arginine, glucagon, propranolol, clonidine and GHRH. A variety of combinations 
of these tests can also be used and, two provocative stimuli can be administered sequentially or in combination. Although these tests have three serious problems: the low specificity, the poor reproducibility, the great variability of the results depending on the type of stimuli [5] and provocative tests are invasive and sometimes has side effects. So, for the definitive diagnosis not only will be necessary the provocative test results, it will always be necessary to take into consideration also the clinical criteria together with auxological and biochemical parameters [6].

By way of summary, the different pharmacological stimuli to measure $\mathrm{GH}$ secretion are shown in table 1. But sometimes, to improve specificity of the test, pharmacological stimuli may be combined as it is shown in table $2[7,8]$.

Table 1. GH Provocative tests.

\begin{tabular}{|c|c|c|c|c|}
\hline GH Provocative test & Drug administration & Blood samples & GH peak & Side effects \\
\hline Insulin Tolerance Test (ITT), i.v & $0.05-0.01 \mathrm{U} / \mathrm{kg}$ & $\begin{array}{l}0 \text { (baseline), 15, 30, 45, } 60 \\
\text { and } 90 \text { minutes }\end{array}$ & $\begin{array}{l}\text { 15-30 minutes after the } \\
\text { glucose nadir }\end{array}$ & Hypoglycaemia \\
\hline L-dopa, i.v. & & & & Nausea, emesis and headache \\
\hline $\begin{array}{l}\text { Arginine } \mathrm{HCl} \text {, i.v (over a } \\
\text { 30-minute period) }\end{array}$ & $0.5 \mathrm{~g} / \mathrm{kg}(\max 40 \mathrm{~g})$ & $\begin{array}{l}0 \text { (baseline), 30, 60, } 90 \text { and } \\
120 \text { minutes }\end{array}$ & $\begin{array}{l}60 \text { minutes after starting } \\
\text { arginine infusion }\end{array}$ & $\begin{array}{l}\text { Nausea and vomiting. Contraindicated in } \\
\text { severe kidney or liver disease }\end{array}$ \\
\hline Glucagon, i.m or s.c. & $0.03 \mathrm{mg} / \mathrm{kg}(\max 1 \mathrm{mg})$ & $\begin{array}{l}0 \text { (baseline), } 30,60,90,120, \\
150 \text { and } 180 \text { minutes }\end{array}$ & $\begin{array}{l}2 \text { hours after glucagon } \\
\text { injection }\end{array}$ & Nausea and vomiting \\
\hline Propranolol (orally)+exercise & $0,5 \mathrm{mg} / \mathrm{Kg}(\mathrm{max} 40 \mathrm{mg})$ & $\begin{array}{l}0,90(20 \text { minutes of intense } \\
\text { exercise), } 120,150 \text { minutes }\end{array}$ & $120-150$ minutes & $\begin{array}{l}\text { Hypoglycaemia, contraindicated in } \\
\text { asthma or cardiac pathology }\end{array}$ \\
\hline Clonidine, i.v & $0.15 \mathrm{mg} / \mathrm{m}^{2}$ & $\begin{array}{l}0 \text { (baseline), 30, } 60 \text { and } 90 \\
\text { minutes }\end{array}$ & $\begin{array}{l}60 \text { minutes after clonidine } \\
\text { administration }\end{array}$ & $\begin{array}{l}\text { Decrease in blood pressure and } \\
\text { drowsiness for several hours }\end{array}$ \\
\hline$G H R H$, i.v & $1 \mathrm{mcg} / \mathrm{kg}$ & $\begin{array}{l}0 \text { (baseline), } 15,30,45,60, \\
90, \text { and } 120 \text { minutes }\end{array}$ & $\begin{array}{l}60 \text { minutes after } \mathrm{GHRH} \\
\text { administration }\end{array}$ & Fainting or feeling light-headed \\
\hline \multicolumn{5}{|l|}{ i.v., intravenously } \\
\hline \multicolumn{5}{|l|}{ i.m., intramuscularly } \\
\hline s.c., subcutaneously & & & & \\
\hline
\end{tabular}

Table 2. GH Provocative tests - pharmacological stimuli combined.

\begin{tabular}{|l|l|l|l|}
\hline GH Provocative test & Procedure & Blood samples & Side effects \\
\hline Arginine i.v. + Insulin i.v. & $\begin{array}{l}\text { First: Arginine dose of } 0.5 \mathrm{~g} / \mathrm{kg} \text { (maximum of } 40 \mathrm{~g}), \\
\text { i.v. and } 60 \mathrm{~min} \text {. later Insulin }(0.05-0.01 \mathrm{U} / \mathrm{kg})\end{array}$ & $\begin{array}{l}0,15,30,45,60,80,90,105, \\
120,150 \text { minutes }\end{array}$ & Nausea and vomiting \\
\hline GHRH i.v.+ArginineHCli.v. & $\begin{array}{l}\mathrm{GHRH} 1 \mu \mathrm{gg} / \mathrm{kg} \text { at time } 0 \text { and Arginine, dose of } 0.5 \mathrm{~g} / \\
\mathrm{kg} \text { (maximum of } 40 \mathrm{~g}), \mathrm{i} . \mathrm{l} .\end{array}$ & $\begin{array}{l}0,30,45,60,90 \text { and } 120 \\
\text { minutes }\end{array}$ & $\begin{array}{l}\text { Fainting or feeling light-headed. Contraindicated } \\
\text { in severe kidney or liver disease }\end{array}$ \\
\hline
\end{tabular}

\section{Results}

Although in all papers reviewed, as shown in table 3, the only of the GH stimulation tests that has obtained $100 \%$ specificity and $100 \%$ sensitivity, it has been the Glucagon test in the study of Eren et al. [9], on the contrary, on the study of Kota et al. [10], the specificity was $85 \%$ and sensitivity was $73 \%$, so it could better be considered that ITT should be one of the preferred GH stimulation tests (gold standard test) [4,11], because it has been the test that has obtained higher percentages of sensitivity and specificity: Borges et al. [12] (sensitivity $100 \%$ and specificity 96,98\%), Guzzetti et al. [13] (sensitivity $94,4 \%$ and specificity $89,6 \%$ ), Rhee et al. [14] (sensitivity $93,6 \%$ and specificity
$78,4 \%$ ), Guo et al. [15] (sensitivity $48 \%$ and specificity $76 \%$ - the lowest percentages of all papers compared), Eren et al. (sensitivity $91 \%$ and specificity $65 \%$ ); Maghnie et al. [16] (sensitivity $96 \%$ and specificity $100 \%$ ), Shalet et al. [4] (sensitivity $100 \%$ and specificity $97 \%$ ) and Tillman et al. [17] (sensitivity $73 \%$ and specificity $85 \%$ ). On the other hand, the other stimulation tests of the GH (L-dopa, Arginine $\mathrm{HCl}$, Clonidine and $\mathrm{GHRH}$ ) could hardly be considered as the gold standard test (in fact, it is not described in the last papers the sensitivity and the specificity about the Propanolol test), because they are not the most used for the detection of growth hormone defects, in addition to the percentages of sensitivity and specificity differ considerably from some studies to others [17-23]. See the values in table 3.

Table 3. The Sensitivity and the Specificity of the tests.

\begin{tabular}{|c|c|c|c|c|c|c|c|}
\hline References & & ITT & L-dopa & Arginine $\mathrm{HCl}$ & Glucagon & Clonidine & GHRH \\
\hline Penta et al. [20] & Sensitivity (\%) & - & - & 97 & - & - & - \\
\hline Int J Environ Res Public Health (2019) & Specificity (\%) & - & - & 100 & - & - & - \\
\hline Borges et al. [13] & Sensitivity (\%) & 100 & - & - & - & 86,8 & - \\
\hline Clinics (2016) & Specificity (\%) & 96,98 & - & - & - & 93,6 & - \\
\hline Dreismann et al. [21] & Sensitivity (\%) & - & - & 91 & - & - & - \\
\hline Growth Horm IGF Res (2016) & Specificity (\%) & - & - & 88 & - & - & - \\
\hline Guzzetti et al. [14] & Sensitivity (\%) & 94,4 & - & 93,9 & - & 88,5 & - \\
\hline Euro J Endocrinology ens (2016) & Specificity (\%) & 89,6 & - & 92,7 & - & 97,3 & - \\
\hline Rhee et al. [15] & Sensitivity (\%) & 93,6 & 79,2 & - & - & - & - \\
\hline Chonnam Med J 2015 & Specificity (\%) & 78,4 & 29,7 & - & - & - & - \\
\hline Obara-Moszynska et al. [22] & Sensitivity (\%) & - & - & - & - & - & 95 \\
\hline Endokrynol Pol 2015 & Specificity (\%) & - & - & - & - & - & 30 \\
\hline Guo et al. [16] & Sensitivity (\%) & 48 & - & - & - & 65 & - \\
\hline Iran J Pediatr 2013 & Specificity (\%) & 76 & - & - & - & 79 & - \\
\hline
\end{tabular}




\begin{tabular}{|c|c|c|c|c|c|c|c|}
\hline Kota et al. [10] & Sensitivity (\%) & - & - & - & 73 & 70 & - \\
\hline J Nepal Paediatr Soc 2012 & Specificity (\%) & - & - & - & 85 & 85 & - \\
\hline Eren et al. [9] & Sensitivity (\%) & 91 & 94 & - & 100 & 72 & - \\
\hline Turk Jem (2010) & Specificity (\%) & 65 & 66 & - & 100 & 90 & - \\
\hline Makimura et al. [23] & Sensitivity (\%) & - & - & 62 & - & - & - \\
\hline J Clin Endocrinol Metab (2008) & Specificity (\%) & - & - & 77 & - & - & - \\
\hline Maghnie et al. [17] & Sensitivity (\%) & 96 & - & - & - & - & - \\
\hline Eur J Endocrinol (2005) & Specificity (\%) & 100 & - & - & - & - & - \\
\hline Shalet et al. [11] & Sensitivity (\%) & 100 & - & - & - & - & - \\
\hline Endocrine Reviews (1998) & Specificity (\%) & 97 & - & - & - & - & - \\
\hline Tillman et al. [19] & Sensitivity (\%) & 73 & - & - & - & - & - \\
\hline J Clin Endocrinol Metab (1997) & Specificity (\%) & 85 & - & - & - & - & - \\
\hline
\end{tabular}

\section{Conclusion}

It has not been possible to establish an ideal pattern against the results obtained in the various stimulation tests could be compared, thus dictating the definition of the sensitivity and specificity of the tests. Because there is a lack of homogeneity in the response of the same patient to two different stimuli: for example, while in some patients hypoglycaemia is a stronger stimulus than exercise and propranolol, in other patients occurs the opposite [18].

On the other hand, stimulation tests may be influenced by factors that must be taken into consideration, such as age, puberty, obesity, hypothyroidism, hypercortisolism, concomitant medication and stress [19].

For all of the above, it must be recognized that it is not surprising that the utility of $\mathrm{GH}$ provocation tests in the diagnosis of $\mathrm{GH}$ deficiency in children with short stature is more questionable. Even so, it would be advisable to use the tests with the highest percentages of sensitivity and specificity to detect subjects with GHD, but always bearing in mind that patients with an adequate $\mathrm{GH}$ response should be excluded beforehand.

\section{References}

1. Collett-Solberg PF, Jorge AAL, Boguszewski MCS, et al. Growth hormone therapy in children; research and practice - A review. Growth Horm IGF Res. 2019; 44: 20-32. doi: 10.1016/j.ghir.2018.12.004

2. Takara S. Diagnosis of Growth Hormone Deficiency in Childhood. Curr Opin Endocrinol Diabetes Obes. 2013; 19(1): 47-52. doi: 10.1097/ MED.0b013e32834ec952

3. Growth Hormone Research Society. Consensus guidelines for the diagnosis and treatment of growth hormone (GH) deficiency in childhood and adolescence: summary statement of the GH Research Society. J Clin Endocrinol Metab. 2000; 85(11): 3990-3993. doi: 10.1210/jcem.85.11.6984

4. Shalet SM, Toogood A, Rahim A, Brennan BM. The diagnosis of growth hormone deficiency in children and adults. Endocr Rev. 1998 19(2): 203223. doi: 10.1210/edrv.19.2.0329

5. García GE. Evidencias en el tratamiento con hormona del crecimiento. Nuevasindicaciones. En: AEPap ed. Curso de Actualización Pediatría. Madrid: Ex- librisEdiciones. 2010: 55-64.

6. Richmond EJ, Rogol AD. Growth hormone deficiency in children. Pituitary. 2008; 11: 115-120. doi: 10.1007/s11102-008-0105-7

7. Bozzola M, Meazza C. Growth Hormone Deficiency: Diagnosis and Therapy in Children. In: Cardenas-Aguayo MC (ed). Restricted Growth - Clinical, Genetic and Molecular Aspects. IntechOpen. 2016:45-72. doi: 10.5772/64803

8. Pombo M, Castro-Feijóo L. Growth hormone: reasonable doubts after more than three decades of experience. Rev Esp Endocrinol Pediatr. 2010; 1.
9. Eren MA, Tabur S, Turan MN, Sanfakiogullan S, SabuncuT. Comparison of Diagnostic Values of Growth Hormone Stimulation Tests in Adolescents. Turk Jem. 2010; 14: 6-9.

10. Kota SK, Jammula S, Gayatri K, Kota SK, Tripathy PR, Modi KD. IGF-1 and IGFBP 3 in Growth Hormone Deficiency Role of Insulin Like Growth Factor-1 (IGF-1) and IGF Binding Protein 3 in the Diagnosis of Growth Hormone Deficiency: Changing Paradigm. Journal of Nepal Paediatric Society. 2012; 32(2): 154-162. doi: 10.3126/jnps.v32i2.5342

11. Guyda HJ. Growth Hormone Testing and the Short Child. Pediatric Research. 2000; 48(5): 579-580.

12. Borges MF, Teixeira FCC, Feltrin AK, et al. Clonidine-stimulated growth hormone concentrations (cut-off values) measured by immunochemiluminescent assay (ICMA) in children and adolescents with short stature. Clinics (Sao Paulo). 2016; 71(4): 226-231.

13. Guzzetti C, Ibba A, Pilia S, et al. Cut-off limits of the peak $\mathrm{GH}$ response to stimulation tests for the diagnosis of GH deficiency in children and adolescents: study in patients with organic GHD. Eur J Endocrinol. 2016; 175(1): 41-47. doi: 10.1530/EJE-16-0105

14. Rhee N, Oh KY, Yang EM, Kim CJ. Growth Hormone Responses to Provocative Tests in Children with short stature. Chonnam Med J. 2015; 51(1): 33-38.

15. Guo C, Chen L. Diagnostic Value of Provocative Test by Insulin Combined with Clonidine for Growth Hormone Deficiency in Children. Iran J Pediatr. 2013; 23(3): 315-320.

16. Maghnie M, Aimaretti $G$, Bellone $S$, et al. Diagnosis of $G H$ deficiency in the transition period: accuracy of insulin tolerance test and insulin- like growth factor-I measurement. Eur J Endocrinol. 2005; 152(4): 589-596. doi: 10.1530/eje.1.01873

17. Tillmann V, Buckler JM, Kibirige MS, et al. Biochemical tests in the diagnosis of childhood growth hormone deficiency. J Clin Endocrinol Metab. 1997; 82(2): 531-535.

18. Gandrud LM, Wilson DM. Is growth hormone stimulation testing in children still appropriate? Growth Horm IGF Res. 2004; 14(3): 185-194. doi: 10.1016/j.ghir.2003.11.003

19. Castro-Feijóo L, Pombo M. Biochemical tests. Rev Horm Crecim. 2002; 5: 36-43.

20. Penta L, Cofini M, Lucchetti L, et al. Growth Hormone (GH) Therapy During the Transition Period: Should We Think about Early Retesting in Patients with Idiopathic and Isolated GH Deficiency?. Int. J. Environ. Res. Public Health. 2019; 16(3): E307. doi: 10.3390/ijerph16030307.

21. Dreismann L, Schweizer R, Blumenstock G, Weber K, Binder G. Evaluation of the GHRH-arginine retest for young adolescents with childhood-onset GH deficiency. Growth Horm IGF Res. 2016; 27:28-32. doi: 10.1016/j. ghir.2016.02.001

22. Obara-Moszynska M, Niedziela M. The usefulness of the GHRH stimulation test in the diagnostics of growth hormone deficiency in children. Endokrynol Pol. 2015; 66 (2): 137-141. doi:10.5603/EP.2015.0021

23. Makimura H, Stanley T, Mun, D, You SM, Grinspoon S. The effects of central adiposity on growth hormone $(\mathrm{GH})$ response to $\mathrm{GH}$-releasing hormone-arginine stimulating testing in men. J Clin Endocrinol Metab. 2008. 93(11): 4254-4260. doi:10.1210/jc.2008-1333 